\title{
Clinical, Physiological and Anti- Inflammatory Effect of Montelukast in Patients with Cough Variant Asthma
}

\author{
Masaya Takemura ${ }^{a}$ Akio Niimi ${ }^{a}$ Hisako Matsumoto ${ }^{a}$ Tetsuya Ueda ${ }^{a}$ \\ Hirofumi Matsuoka ${ }^{a}$ Masafumi Yamaguchia Makiko Jinnai ${ }^{a}$ Kazuo Chin $^{\mathrm{b}}$ \\ Michiaki Mishima ${ }^{a}$ \\ Departments of a Respiratory Medicine and ${ }^{b}$ Respiratory Care and Sleep Control Medicine, Kyoto University, \\ Kyoto, Japan
}

\section{Key Words}

Cough variant asthma $\cdot$ Leukotriene receptor antagonist •

Montelukast • Induced sputum • Cysteinyl leukotrienes •

Eosinophils $\cdot$ Cough receptor sensitivity

\begin{abstract}
Background: Cough variant asthma (CVA) is a phenotype of asthma presenting solely with coughing, characterized by airway hyperresponsiveness, eosinophilic inflammation and a cough response to bronchodilators. Leukotriene receptor antagonists (LTRAs) are antiasthma medications with antiinflammatory and bronchodilatory properties. Although LTRAs exert antitussive effects in CVA, the mechanisms involved are unknown. Objectives: This study aimed to clarify the antitussive mechanisms of LTRAs in CVA patients. Methods: We prospectively observed the effect of montelukast (10 mg) daily for 4 weeks in 23 consecutive nonsmoking adults with anti-inflammatory treatment-naive CVA. We evaluated, before and after treatment, the cough visual analogue scale (VAS), pulmonary function (spirometry and impulse oscillation), methacholine airway responsiveness, cough receptor sensitivity, expressed by the concentration of capsaicin inducing 2 or more (C2) and 5 or more (C5)
\end{abstract}

coughs, sputum eosinophil counts and levels of inflammatory mediators, including cysteinyl leukotrienes, leukotriene $B_{4}$, prostaglandin (PG) $D_{2}, P E_{2}, P_{2 \alpha}$ and thromboxane $B_{2}$. We compared the baseline characteristics of the patients based on the symptomatic response to montelukast, defined as a decrease in the cough VAS of $>25 \%(n=15)$ or $\leq 25 \%$ ( $n=8$ ). Results: Montelukast significantly decreased the cough VAS ( $p=0.0008)$, sputum eosinophil count ( $p=$ $0.013)$ and cough sensitivity ( $C 2: p=0.007 ; C 5: p=0.039)$, whereas pulmonary function, airway responsiveness and sputum mediator levels remained unchanged. Multivariate analysis showed that a better response to montelukast was associated solely with younger age $(p=0.032)$. Conclusion: The antitussive effect of montelukast in CVA may be attributed to the attenuation of eosinophilic inflammation rather than its bronchodilatory properties.

Copyright $\odot 2011$ S. Karger AG, Basel

\section{Introduction}

Cough variant asthma (CVA) is a variant form of asthma that presents solely with cough [1] and is one of the most common causes of chronic cough worldwide [2]. $\mathrm{Pa}$ -

\section{KARGER}

Fax +4161306 1234 E-Mail karger@karger.ch www.karger.com

\section{(C) 2011 S. Karger AG, Basel}

0025-7931/12/0834-0308\$38.00/0

Accessible online at:

www.karger.com/res
Akio Niimi

Department of Respiratory Medicine

Postgraduate School of Medicine, Kyoto University

Sakyo-ku, Kyoto 606-8507 (Japan)

Tel. +81 75751 3830,E-Mail niimi@kuhp.kyoto-u.ac.jp 
tients with CVA have mild airway hyperresponsiveness (AHR), as demonstrated by methacholine challenge, and bronchodilators such as inhaled $\beta_{2}$-agonists and/or oral sustained-release theophyllines are effective against the cough [1]. Modest but variable airflow limitation indicates that bronchial constriction is involved in the mechanism of cough in CVA [3].

Findings in induced sputum, bronchoalveolar lavage and bronchial biopsies have shown that eosinophilic inflammation is involved in CVA as well as in classic asthma with wheezing $[4,5]$. Several inflammatory mediators are also implicated in CVA $[6,7]$. Prostanoids such as prostaglandin (PG) $\mathrm{E}_{2}, \mathrm{PGF}_{2 \alpha}$ and thromboxane (TX) $\mathrm{A}_{2}$ modulate airway caliber $[8,9]$ and enhance the cough response to capsaicin $[10,11]$, which is produced by various cells including eosinophils [12]. Metabolites of lipoxygenase products have recently been identified as ligands of the transient receptor potential vanilloid 1 receptor, also known as the capsaicin receptor $[13,14]$.

Cysteinyl leukotriene (cys-LT) receptor antagonists (LTRAs) are antiasthma medications that reduce clinical symptoms and improve pulmonary function as well as airway inflammation in patients with classic asthma $[15$, 16]. An uncontrolled observational study has shown that the LTRA montelukast reduces airway levels of cys-LTs in association with improvements in the quality of life of patients with classic asthma already under treatment with inhaled corticosteroids (ICS) [17]. Although LTRAs exert antitussive effects in CVA [18-20], details of the mechanisms underlying these effects, including anti-inflammatory effects, remain unknown.

The present study examined the effect of montelukast on cough symptoms, pulmonary function, capsaicin cough receptor sensitivity, AHR and sputum inflammatory indices including numbers of eosinophils and levels of inflammatory mediators [cys-LTs, leukotriene $\mathrm{B}_{4}$ $\left(\mathrm{LTB}_{4}\right), \mathrm{PGD}_{2}, \mathrm{PGE}_{2}, \mathrm{PGF}_{2 \alpha}$ and $\mathrm{TXB}_{2}$ ] in patients with $\mathrm{CVA}$, in order to investigate its antitussive mechanisms.

\section{Patients and Methods}

\section{Study Design}

This was a prospective observational study. To elucidate the antitussive mechanism of montelukast, we measured, before and after treatment, cough symptoms, pulmonary function, capsaicin cough receptor sensitivity, AHR and sputum inflammatory indices including eosinophil counts and levels of mediators such as cys-LTs, $\mathrm{LTB}_{4}, \mathrm{PGD}_{2}, \mathrm{PGE}_{2}, \mathrm{PGF}_{2 \alpha}$ and $\mathrm{TXB}_{2}$ in patients with CVA. The study was approved by the Institutional Review Board of Kyoto University Hospital, and written informed consent was obtained from all participants.

Effects of Montelukast in Cough Variant Asthma
Patients

Twenty-three consecutive patients with CVA (9 males and 14 females; mean age (SD) 46 (16) years) who were referred to the asthma and chronic cough clinic at Kyoto University Hospital were recruited between March 2002 and June 2005. The duration of cough was 3.5 (3.3) years. Nineteen of the patients had never smoked. Four had smoked less than 5 pack-years but had stopped smoking for more than 3 years before entry into the study.

CVA was diagnosed on the basis of chronic cough persisting for $>8$ weeks, the absence of wheezing or dyspnea, AHR to methacholine and a symptomatic response of coughing to inhaled $\beta_{2^{-}}$ agonists (used as needed or 4 times per day) $[1,4,21]$. Wheezing or rhonchi were not audible on chest auscultation, even with forced expiration. The patients had normal chest radiographs and no history of asthma or other respiratory diseases. No other causes of cough were present, such as gastroesophageal reflux disease or sinobronchial syndrome. None of the patients had ever been administered oral corticosteroids or ICS, antileukotriene drugs, sustained-release theophyllines, TX synthase inhibitors or receptor antagonists, cyclooxygenase inhibitors or angiotensinconverting enzyme inhibitors, or had had an upper respiratory infection within the previous 8 weeks.

\section{Study Protocol}

Prebronchodilator pulmonary function was initially determined by impulse oscillometry (IOS) [22] and spirometry, methacholine challenge and sputum induction, in that order. Seven days later, the patients indicated their cough severity during the previous 7 days on a linear visual analogue scale (VAS) on which $0 \mathrm{~mm}$ represents no cough and $100 \mathrm{~mm}$ the worst cough [23]. Capsaicin cough challenge was performed on the same day, and montelukast (Kipres, Kyorin Pharmaceutical Co. Ltd., Tokyo, Japan; 10 mg/ day) was administered in an uncontrolled, open-label fashion for 4 weeks. This is considered long enough to examine the effect of montelukast on cough symptoms and cough receptor hypersensitivity in CVA $[18,19]$. After 4 weeks, spirometry, IOS, methacholine challenge and sputum induction were repeated, followed by capsaicin cough challenge 1 week later while the patients were still receiving montelukast.

\section{Sputum Induction and Processing}

Sputum was induced and processed as described previously $[24,25]$. Briefly, after premedication with inhaled sulbutamol, the subjects inhaled hypertonic (3\%) saline solution for $15 \mathrm{~min}$, delivered using an ultrasonic nebulizer. The sputum was processed for dispersed cell total and differential counts. Supernatants were stored at $-80^{\circ} \mathrm{C}$ for subsequent mediator measurements. Sputum induction was carried out within $1 \mathrm{~h}$ after the methacholine challenge test. Methacholine does not alter the cellular and biochemical constituents of sputum [26].

Measurement of Sputum Levels of Inflammatory Mediators

Concentrations of cys-LTs, $\mathrm{LTB}_{4}, \mathrm{PGD}_{2}$-methoxime, $\mathrm{PGE}_{2}$, $\mathrm{PGF}_{2 \alpha}$ and $\mathrm{TXB}_{2}$ in the supernatant of induced sputum were measured with sandwich enzyme immunoassay kits (cys-LTs and $\mathrm{PGE}_{2}$ : Amersham Biosciences Corp., N.J., USA; $\mathrm{LTB}_{4}, \mathrm{PGD}_{2^{-}}$ methoxime, $\mathrm{PGF}_{2 \alpha}$ and $\mathrm{TXB}_{2}$ : Cayman Chemical, Ann Arbor, Mich., USA) according to the manufacturers' instructions. Duplicate measurements were averaged for analysis. Because $\mathrm{PGD}_{2}$ and $\mathrm{TXA}_{2}$ are both relatively unstable, we measured $\mathrm{PGD}_{2}$-methox- 
ime and $\mathrm{TXB}_{2}$, which are stable derivatives of $\mathrm{PGD}_{2}$ and $\mathrm{TXA}_{2}$, respectively [7]. The detection limit of each mediator was 10, 13, 3.1, 40, 8 and $11 \mathrm{pg} / \mathrm{ml}$ for cys-LTs, $\mathrm{LTB}_{4}, \mathrm{PGD}_{2}$-methoxime, $\mathrm{PGE}_{2}, \mathrm{PGF}_{2 \alpha}$ and $\mathrm{TXB}_{2}$, respectively.

\section{Pulmonary Function}

We conducted IOS using an MS-IOS (Erich Jaeger, Hoechberg, Germany) as described elsewhere [25, 27-29] and according to standard recommendations [30]. We measured R5 and R20 as indices of total and proximal airway resistance, respectively, and considered the difference between them (R5 - R20) a surrogate marker of small airway resistance. Reactance at $5 \mathrm{~Hz}$ (X5) was also measured as an index of peripheral airway abnormalities [22, 25, $29,30]$. IOS is a simple and noninvasive method of assessing pulmonary function without forced maneuvers, and the indices respond to therapeutic intervention or correlate with pathophysiological indices more sensitively than those of spirometry $[25,27-$ 29, 31].

The spirometric indices forced expiratory volume in $1 \mathrm{~s}\left(\mathrm{FEV}_{1}\right)$ and mid-forced expiratory flow $\left(\mathrm{FEF}_{25-75 \%}\right)$, as well as the reversibility of $\mathrm{FEV}_{1}$ with a $\beta$-agonist, were measured according to recent recommendations [32].

\section{Capsaicin Cough Challenge}

Capsaicin cough receptor sensitivity was measured as described previously with slight modifications [33]. Briefly, 10 doubling concentrations of capsaicin (0.61-312.5 $\mu \mathrm{M})$ were inhaled during tidal breathing until 2 or more coughs and 5 or more coughs were induced (cough thresholds C2 and C5, respectively). The patients inhaled a saline control followed by progressively increasing concentrations of capsaicin. Each 15-second capsaicin inhalation was interspersed with saline inhalation for $45 \mathrm{~s}$ as a blind.

\section{Methacholine AHR}

AHR was examined by continuous methacholine inhalation with simultaneous measurement of respiratory resistance (Rrs; $\mathrm{cm} \mathrm{H}_{2} \mathrm{O} / \mathrm{l} / \mathrm{s}$ ) (Astograph; Chest, Tokyo, Japan) [34]. Briefly, twofold increasing concentrations of methacholine solution in 10 dose steps $(49-25,000 \mu \mathrm{g} / \mathrm{ml})$ were prepared. They were inhaled during tidal breathing from nebulizers with an output of $0.15 \mathrm{ml} /$ $\mathrm{min}$. After recording the baseline Rrs during inhalation of physiologic saline for $1 \mathrm{~min}$, methacholine was inhaled sequentially, starting from the lowest concentration, at 1-min intervals. The cumulative dose of inhaled methacholine at the inflection point at which Rrs begins to increase (Dmin) was used as the index of airway sensitivity. This variable was measured in terms of a unit defined as 1 -min inhalation of $1 \mathrm{mg} / \mathrm{ml}$ methacholine. Inhalation of methacholine was continued until Rrs reached twice the baseline value. The slope of the methacholine-Rrs dose-response curve (SRrs) was used as the measure of airway reactivity. The total cumulative dose of methacholine after inhalation of the highest dose was 50 units.

This method was developed and established by Takishima et al. [34] and further validated by our group [35].

\section{Response to Montelukast}

Patients were assigned to groups according to their response to montelukast. A better symptomatic response to montelukast was arbitrarily defined as a $>25 \%$ decrease in VAS ( $\Delta$ VAS $>25 \%)$.
Table 1. Changes in 23 patients treated with montelukast for 4 weeks

\begin{tabular}{|c|c|c|c|}
\hline & \multicolumn{2}{|c|}{ Montelukast treatment } & \multirow{2}{*}{$\begin{array}{l}\mathrm{p} \\
\text { value }\end{array}$} \\
\hline & before & after & \\
\hline Cough VAS, mm & $40.3(22.1)$ & $19.3(14.8)$ & 0.0008 \\
\hline $\mathrm{FEV}_{1}, \%$ predicted & $103(13)$ & $106(16)$ & 0.13 \\
\hline $\mathrm{FEF}_{25-75 \%}, \%$ predicted & $96(30)$ & $101(32)$ & 0.65 \\
\hline $\mathrm{R} 5, \mathrm{kPa} / \mathrm{l} / \mathrm{s}$ & $0.31(0.10)$ & $0.33(0.11)$ & 0.89 \\
\hline $\mathrm{R} 20, \mathrm{kPa} / \mathrm{l} / \mathrm{s}$ & $0.27(0.07)$ & $0.28(0.07)$ & 0.96 \\
\hline $\mathrm{R} 5$ - R20, $\mathrm{kPa} / \mathrm{l} / \mathrm{s}$ & $0.04(0.04)$ & $0.05(0.05)$ & 0.42 \\
\hline $\mathrm{X} 5, \mathrm{kPa} / \mathrm{l} / \mathrm{s}$ & $-0.12(0.06)$ & $-0.11(0.06)$ & 0.60 \\
\hline $\log \mathrm{C} 2, \mu \mathrm{M}$ & $0.49(0.72)$ & $0.77(0.75)$ & 0.007 \\
\hline $\log C 5, \mu \mathrm{M}$ & $0.79(0.75)$ & $0.98(0.74)$ & 0.039 \\
\hline $\log$ Dmin, units & $0.32(1.08)$ & $0.70(0.58)$ & 0.51 \\
\hline $\mathrm{SRrs}, \mathrm{cm} \mathrm{H}_{2} \mathrm{O} / \mathrm{l} / \mathrm{s} / \mathrm{min}$ & $2.08(1.64)$ & $1.93(1.48)$ & 0.65 \\
\hline \multicolumn{4}{|l|}{ Sputum indices } \\
\hline Eosinophils, $\times 10^{5} / \mathrm{g}$ & $1.23(3.36)$ & $0.55(1.25)$ & 0.013 \\
\hline cys-LTs, ng/ml & $18.4(15.8)$ & $12.8(14.7)$ & 0.50 \\
\hline $\mathrm{LTB}_{4}, \mathrm{ng} / \mathrm{ml}$ & $5.24(6.37)$ & $4.86(6.94)$ & 0.96 \\
\hline $\mathrm{PGD}_{2}, \mathrm{ng} / \mathrm{ml}$ & $0.14(0.29)$ & $0.05(0.05)$ & 0.21 \\
\hline $\mathrm{PGE}_{2}, \mathrm{ng} / \mathrm{ml}$ & $1.25(1.11)$ & $1.11(0.91)$ & 0.69 \\
\hline $\mathrm{PGF}_{2 \alpha}, \mathrm{ng} / \mathrm{ml}$ & $0.83(0.62)$ & $0.74(0.49)$ & 0.80 \\
\hline $\mathrm{TXB}_{2}, \mathrm{ng} / \mathrm{ml}$ & $1.94(1.79)$ & $1.58(1.41)$ & 0.59 \\
\hline
\end{tabular}

Data are means (SD).

Baseline characteristics, including physiological and inflammatory indices, of these patients were compared with those of the remaining patients ( $\triangle$ VAS $\leq 25 \%$ ).

\section{Statistical Analysis}

Values are expressed as means (SD). Changes in symptoms after treatment with montelukast were analyzed using the Wilcoxon signed-rank test. Subgroups classified according to the response to montelukast were compared by univariate analysis using the Mann-Whitney U test or Fisher's exact probability test. Independent factors associated with the response to treatment were tested using logistic regression analysis. $p$ values of $<0.05$ were considered statistically significant.

\section{Results}

\section{Effect of Montelukast}

Table 1 and figure 1 show changes in symptoms, physiological indices and inflammatory parameters of sputum before and after treatment with montelukast. The cough VAS improved from 40.3 (22.1) to 19.3 (14.8) $\mathrm{mm}$ after 4 weeks $(\mathrm{p}=0.008)$, with a mean $(\mathrm{SD})$ improvement rate of $52.2 \%$ (33.0). With respect to cough receptor sensitivity, C2 increased in 13 of the 23 patients (57\%) after 


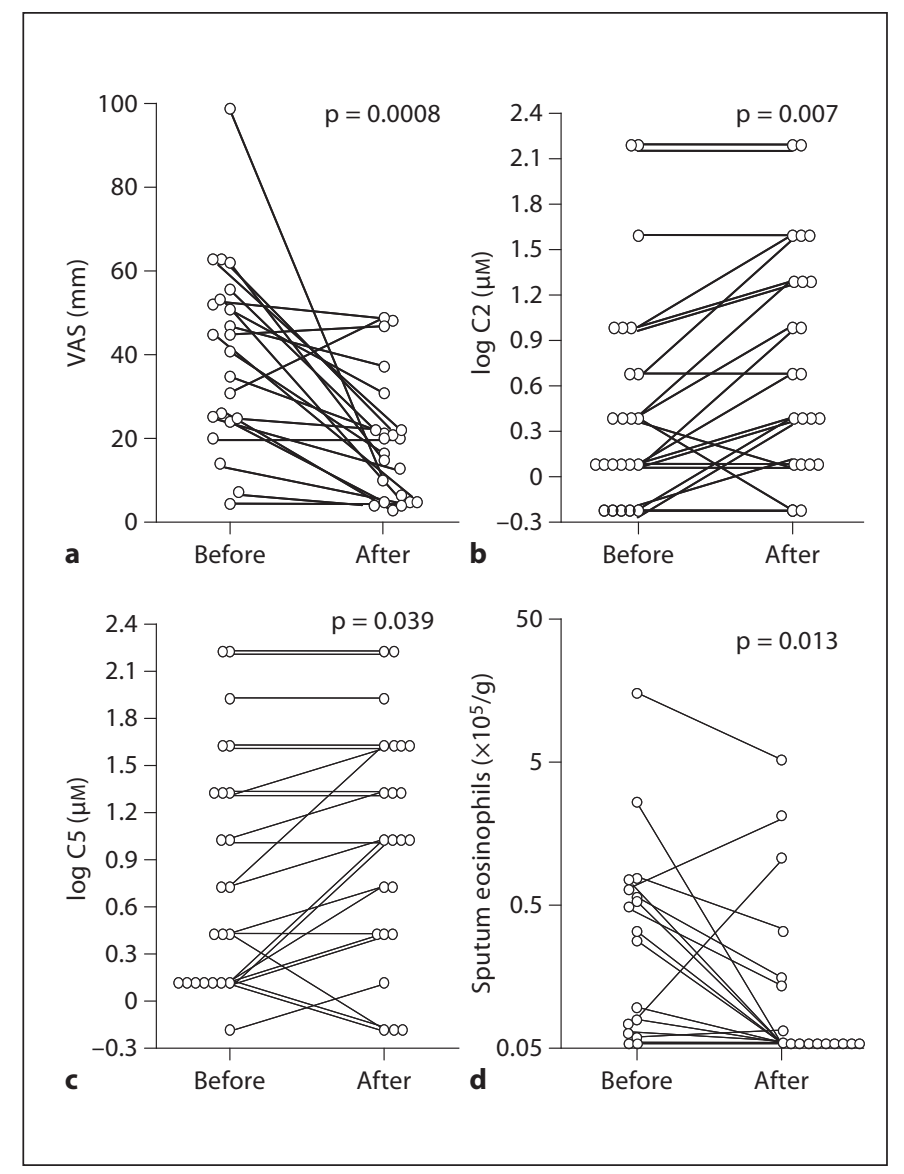

Fig. 1. Effects of montelukast for 4 weeks on cough VAS (a), $\log \mathrm{C} 2$ (b), $\log$ C5 (c) and sputum eosinophil counts (d) in patients with CVA.

treatment but did not change in 8 and decreased in 2, while $\log \mathrm{C} 2$ improved from 0.49 (0.72) to $0.77(0.75) \mu \mathrm{M}$ $(\mathrm{p}=0.007)$. Also, C5 increased in 11 patients $(48 \%)$ but was unchanged in 9 and decreased in 3; log C5 improved from $0.79(0.75)$ to $0.98(0.74) \mu \mathrm{M}(\mathrm{p}=0.039)$. Adequate pairs of sputum samples were collected from 17 of the 23 patients before and after treatment. The number of sputum eosinophils decreased with treatment from 1.23 (3.36) to $0.55(1.25) \times 10^{5} / \mathrm{g}(\mathrm{p}=0.013)$. However, spirometric and IOS indices, airway sensitivity and reactivity, and sputum levels of cys-LTs, $\mathrm{LTB}_{4}, \mathrm{PGD}_{2}, \mathrm{PGE}_{2}, \mathrm{PGF}_{2 \alpha}$ and $\mathrm{TXB}_{2}$ did not change significantly (table 1 ).

\section{Baseline Clinical Characteristics according to Response to Montelukast}

The symptomatic response to montelukast was better $(\Delta$ VAS $>25 \%)$ in 15 of the 23 patients (65\%). The results
Table 2. Baseline characteristics of patient subgroups according to montelukast response

\begin{tabular}{|c|c|c|c|}
\hline & \multicolumn{2}{|c|}{ Response to montelukast } & \multirow{2}{*}{$\begin{array}{l}\mathrm{p} \\
\text { value }\end{array}$} \\
\hline & $\Delta \mathrm{VAS}>25 \%$ & $\Delta \mathrm{VAS} \leq 25 \%$ & \\
\hline Male/female, $\mathrm{n}$ & $5 / 10$ & $4 / 4$ & 0.66 \\
\hline Age, years & $42(13)$ & $56(13)$ & 0.026 \\
\hline Disease duration, years & $3.6(4.0)$ & $3.2(2.0)$ & 0.56 \\
\hline Nonsmokers/ex-smokers, $\mathrm{n}$ & $13 / 2$ & $6 / 2$ & 0.59 \\
\hline Atopy/nonatopy ${ }^{\mathrm{a}}, \mathrm{n}$ & $9 / 6$ & $4 / 4$ & 0.68 \\
\hline $\mathrm{FEV}_{1}, \%$ predicted & $100(12)$ & $110(12)$ & 0.053 \\
\hline $\mathrm{FEF}_{25-75 \%}, \%$ predicted & $91(29)$ & $104(31)$ & 0.20 \\
\hline $\mathrm{FEV}_{1} \beta_{2}$ reversibility, \% & $4.4(6.1)$ & $2.1(3.6)$ & 0.24 \\
\hline $\mathrm{R} 5, \mathrm{kPa} / \mathrm{l} / \mathrm{s}$ & $0.31(0.11)$ & $0.31(0.08)$ & 0.61 \\
\hline $\mathrm{R} 20, \mathrm{kPa} / \mathrm{l} / \mathrm{s}$ & $0.26(0.08)$ & $0.27(0.07)$ & 0.75 \\
\hline $\mathrm{R} 5$ - R20, $\mathrm{kPa} / \mathrm{l} / \mathrm{s}$ & $0.04(0.04)$ & $0.04(0.03)$ & 0.97 \\
\hline $\mathrm{X} 5, \mathrm{kPa} / \mathrm{l} / \mathrm{s}$ & $-0.14(0.07)$ & $-0.09(0.03)$ & 0.14 \\
\hline $\log \mathrm{C} 2, \mu \mathrm{M}$ & $0.3(0.5)$ & $0.8(0.9)$ & 0.19 \\
\hline $\log \mathrm{C} 5, \mu \mathrm{M}$ & $0.8(0.7)$ & $1.0(0.9)$ & 0.77 \\
\hline $\log$ Dmin, units & $0.047(0.93)$ & $0.77(1.2)$ & 0.030 \\
\hline $\mathrm{SRrs}, \mathrm{cm} \mathrm{H}{ }_{2} \mathrm{O} / \mathrm{l} / \mathrm{s} / \mathrm{min}$ & $2.26(1.94)$ & $1.71(0.58)$ & 0.54 \\
\hline Sputum indices & $(\mathrm{n}=9)$ & $(\mathrm{n}=8)$ & \\
\hline Eosinophils, $\times 10^{5} / \mathrm{g}$ & $0.54(0.73)$ & $2.00(4.9)$ & 0.81 \\
\hline cys-LTs, ng/ml & $17.6(16.8)$ & $19.6(15.5)$ & 0.85 \\
\hline $\mathrm{LTB}_{4}, \mathrm{ng} / \mathrm{ml}$ & $3.55(3.76)$ & $7.14(8.23)$ & 0.56 \\
\hline $\mathrm{PGD}_{2}, \mathrm{ng} / \mathrm{ml}$ & $0.21(0.40)$ & $0.06(0.05)$ & 0.44 \\
\hline $\mathrm{PGE}_{2}, \mathrm{ng} / \mathrm{ml}$ & $1.16(1.12)$ & $1.37(1.16)$ & 0.70 \\
\hline $\mathrm{PGF}_{2 \alpha}, \mathrm{ng} / \mathrm{ml}$ & $0.85(0.70)$ & $0.80(0.55)$ & $>0.99$ \\
\hline $\mathrm{TXB}_{2}, \mathrm{ng} / \mathrm{ml}$ & $2.18(2.10)$ & $1.60(1.32)$ & 0.77 \\
\hline
\end{tabular}

Data are means (SD)

a Atopy is defined as the presence of at least one positive specific IgE response against eight common allergens [61].

of the univariate analysis showed that the better respondents were significantly younger $(p=0.026)$ and more sensitive to methacholine $(\mathrm{p}=0.030)$ than those with $\Delta$ VAS $\leq 25 \%$ (table 2). Other indices, including IOS and spirometry, $\log$ C5, airway reactivity, sputum eosinophil count and sputum mediator levels including that of cysLTs, did not differ between the subgroups. Montelukast responses, assessed as the percentage change in physiological indices $\left(\mathrm{FEV}_{1}, \mathrm{FEF}_{25-75 \%}, \mathrm{R} 5, \mathrm{R} 20\right.$, R5 - R20, X5, $\log$ C2, $\log$ C5, $\log$ Dmin or SRrs) and the number of sputum eosinophils, also did not differ between subgroups (data not shown). Multiple linear regression analysis including age and log Dmin identified younger age as the sole predictor of a better responsiveness to montelukast (table 3).

An analysis of 17 patients who had adequate pairs of sputum samples before and after treatment revealed no 
Table 3. Multiple regression model for better response to montelukast

\begin{tabular}{lll}
\hline & Odds ratio & p value \\
\hline Age & $0.89(0.78-0.99)$ & 0.032 \\
$\log$ Dmin & $0.26(0.063-1.08)$ & 0.064 \\
\hline
\end{tabular}

Values in parentheses represent $95 \%$ confidence intervals.

significant correlations among percentage changes in VAS, sputum eosinophils, $\log \mathrm{C} 2$ and $\log$ C5 (data not shown). In addition, percentage changes in the sputum eosinophil count were unrelated to those in sputum mediator levels (data not shown). In all of the 23 subjects, percentage changes in VAS were also unrelated to those in $\mathrm{C} 2$ or C5 (data not shown).

\section{Discussion}

We investigated the clinical, physiological and antiinflammatory effects of montelukast in patients with CVA. Effects on the cough VAS and cough receptor sensitivity were confirmed as in other studies $[18,19]$. We also discovered a significant decrease in sputum eosinophil count, although IOS and spirometry indices remained unchanged.

Ample evidence supports the effectiveness of LTRAs against classic asthma $[15,16,36]$, and their value against CVA has also been reported [18-20, 37]. A placebo-controlled crossover study found that 2 weeks of treatment with zafirlukast significantly improved cough scores and capsaicin cough receptor sensitivity in 8 patients with CVA, while $\mathrm{FEV}_{1}$ values remained unchanged [18]. Four weeks of treatment with montelukast improved subjective and objective measures of cough frequency and scores on the Asthma Quality of Life questionnaire without a concomitant change in $\mathrm{FEV}_{1}$ in 8 patients with CVA, as compared with 6 who received a placebo [19]. However, the antitussive mechanisms of the LTRAs were not examined in these small studies, except for one analysis of bronchial tissue from a subset of patients $(n=13)$, which showed that responders to montelukast had increased numbers of CD63-positive cells (activated mast cells) compared with nonresponders [37].

Airflow limitation is usually minimal in CVA, as it was in our patients, while being involved in the pathogenesis of cough in CVA that is attenuated by bronchodila- tors $[1,3,4,21]$. Airway caliber changes that may be missed by spirometry can be sensitively detected by IOS $[22,25,27-29,31]$, but we found no significant changes in indices of IOS, nor in indices of spirometry, after treatment with montelukast, which was consistent with previous findings $[18,19]$. The antitussive effect of montelukast in CVA may thus be attributable to its anti-inflammatory properties that attenuate eosinophilic inflammation rather than to bronchodilation.

Tussive inflammatory mediators, which may activate afferent sensory nerve endings, have been implicated in the pathogenesis of cough $[7,38,39]$. Inhalation studies in healthy individuals $[9,10]$ and inhibition studies of the specific antagonists of inflammatory mediators in asthmatic patients [11] have shown that prostanoids such as $\mathrm{PGE}_{2}, \mathrm{PGF}_{2 \alpha}$ and $\mathrm{TXA}_{2}$ are associated with the cough reflex. A recent in vitro study revealed that the metabolites of lipoxygenase products such as 12- and 15-(S)hydroperoxyeicosatetraenoic acids, 5- and 15-(S)-hydroxyeicosatetraenoic acids and $\mathrm{LTB}_{4}$ might be ligands for transient receptor potential vanilloid 1 receptors [13]. The expression of such receptors is increased in the airways of patients with chronic cough, including those with CVA [40], indicating their involvement in cough hypersensitivity [14]. However, evidence supporting direct tussive effects of cys-LTs on 'cough receptors' is scarce.

Montelukast decreases cys-LT levels in the exhaled breath of patients with classic asthma [17, 41]. To our knowledge, this is the first study to investigate the detailed anti-inflammatory effect of an LTRA in CVA, and we revealed that montelukast significantly decreased sputum eosinophils as well as the cough VAS and capsaicin sensitivity but did not affect sputum levels of cys-LTs, $\mathrm{LTB}_{4}, \mathrm{PGD}_{2}, \mathrm{PGE}_{2}, \mathrm{PGF}_{2 \alpha}$ and $\mathrm{TXB}_{2}$. Since eosinophils are a source of various prostanoids [12] and cys-LTs [42], we postulated that montelukast exerts antitussive effects by attenuating eosinophilic inflammation with a resultant fall in some prostanoid and cys-LT levels in CVA. However, our results disproved this notion. Percentage changes in sputum eosinophils were unrelated to those of sputum levels of mediators, including cys-LTs.

With respect to cys-LTs, the discrepancy of the results between the previous breath condensate studies conducted in classic asthma patients presenting with wheezing $[17,41]$ and our sputum study of CVA patients may have derived from possible pathophysiological differences between CVA and classic asthma. In CVA and the related condition eosinophilic bronchitis, activation of 
mast cells has been indicated by the increased sputum levels of the mast cell-derived tussive mediators histamine and $\mathrm{PGD}_{2}$ [7], while this is not a feature of classic asthma [43]. A recent bronchial biopsy study has also implicated the activation of mast cells in the pathophysiology of CVA [37]. Such evidence may suggest that mast cells rather than eosinophils are a relatively more important source of cys-LTs in patients with CVA as compared with those with classic asthma. As for other mediators measured in this study, major cellular sources are cells other than eosinophils (e.g. mast cells for $\mathrm{PGD}_{2}$, alveolar macrophages for $\mathrm{PGE}_{2}$ and neutrophils for $\mathrm{LTB}_{4}$ ) [44] which are poorly responsive to LTRAs, unlike eosinophils. This may explain why our mechanistic hypothesis was not verified. Since ICS, which are potent inhibitors of eosinophilic inflammation, do not alter cough sensitivity in CVA [45], whereas LTRAs do, as we and others [18] have shown, LTRAs might exert a different antitussive mechanism from ICS.

In a study by Birring et al. [7], sputum mediator levels were measured in 18 healthy subjects and in three subgroups of chronic cough patients (CVA or eosinophilic bronchitis, $n=20$; various causes of nonasthmatic cough, $\mathrm{n}=20$; idiopathic cough, $\mathrm{n}=22$ ). Levels of $\mathrm{PGD}_{2}$ and $\mathrm{PGE}_{2}$ were significantly higher in all cough subgroups compared with controls, and histamine levels were also increased in the CVA and eosinophilic bronchitis and idiopathic cough subgroups, whereas cys-LT levels were increased only in the CVA and eosinophilic bronchitis subgroup. These results indicate that cys-LTs are specifically involved in cough associated with eosinophilic airway disorders, whereas $\mathrm{PGD}_{2}, \mathrm{PGE}_{2}$ and histamine are universally involved in the common mechanism of cough.

One possible mechanism for the association of cys-LTs with cough in CVA is via the tussive mediator substance $\mathrm{P}$. The expression of substance $\mathrm{P}$ in the airway epithelium is increased in CVA patients compared with classic asthma patients and healthy subjects, both of whom express similar amounts of substance $\mathrm{P}$ [46]. We have also reported that plasma levels of substance $\mathrm{P}$ are elevated in patients with CVA and cough-predominant asthma as compared with healthy subjects [47]. cys-LTs induce the release of substance $\mathrm{P}$ through the stimulation of airway afferent nerve fibers [48], and LTRAs inhibit such release $[48,49]$. Evidence that LTRAs attenuate cough receptor sensitivity in CVA [18] but not classic asthma [50] might be consistent with this hypothesis, but the details remain to be clarified.
The effect of LTRAs in classic asthma is variable. This has been attributed to the effects of genetics [51], smoking [52] and also age. Symptoms and lung function respond better to zafirlukast in patients aged $<65$ years than in older patients [53]. The effect of zafirlukast is better among patients aged $<50$ years $[54,55]$. Our results are consistent with these findings, but the mechanisms involved are unknown. Sputum levels of mediators mainly derived from mast cells, such as $\mathrm{PGD}_{2}$, were not increased in our patients with better responses to montelukast, which contradicts the suggested hypothesis [37].

Some limitations of our study should be noted. We arbitrarily defined a better response to montelukast as a $>25 \%$ decrease of VAS based on our clinical experience, not on evidence. The European Respiratory Society guidelines on the assessment of cough recommend using the cough VAS for assessment of chronic cough severity [23]. Actually, there is evidence that the cough VAS score is highly reproducible [56] and responsive to intervention [57] when used as an outcome measure in clinical studies of chronic cough. However, the minimal change in VAS needed to judge the efficacy of intervention remains to be determined. The British Thoracic Society guidelines of cough have defined the minimal significant improvement of cough as a change in VAS of $15 \mathrm{~mm}$ [58]. However, this is not even based on evidence. We readily admit that future validation studies are essential for this issue. The lack of a control group is another limitation of our study. This might have affected the precise evaluation of treatment effects. However, a placebo effect of montelukast upon sputum eosinophils and coughing that had persisted for an average of 3.5 years seems unlikely. We believe that the observed efficacy of montelukast on the cough VAS, cough sensitivity and sputum eosinophilia but not on pulmonary function measures is relevant in the absence of controls. Moreover, this short-term study could not investigate the effect of treatment on the longterm consequences of disease such as the development of irreversible airflow obstruction [1], airway remodeling [5, 59] and progression to classic asthma, which might be preventable by ICS [60].

In conclusion, we found that the cough VAS, sputum eosinophil counts and cough sensitivity significantly improved in CVA patients treated with montelukast for 4 weeks, while pulmonary function did not change. The antitussive effect of montelukast in CVA might be attributable to its anti-inflammatory ability rather than bronchodilation. However, the detailed mechanisms remain to be clarified by future controlled studies. 


\section{References}

$\checkmark 1$ Niimi A, Matsumoto H, Mishima M: Eosinophilic airway disorders associated with chronic cough. Pulm Pharmacol Ther 2009; 22:114-120.

$>2$ Niimi A: Geography and cough aetiology. Pulm Pharmacol Ther 2007;20:383-387.

$\checkmark 3$ Sano T, Ueda H, Bando H: A preliminary study of PEFR monitoring in patients with chronic cough. Lung 2004;182:285-295.

$\checkmark 4$ Niimi A, Amitani R, Suzuki K, Tanaka E, Murayama T, Kuze F: Eosinophilic inflammation in cough variant asthma. Eur Respir J 1998;11:1064-1069.

$\checkmark 5$ Niimi A, Torrego A, Nicholson AG, Cosio BG, Oates TB, Chung KF: Nature of airway inflammation and remodeling in chronic cough. J Allergy Clin Immunol 2005;116: 565-570.

66 Forsythe P, McGarvey LP, Heaney LG, MacMahon J, Ennis M: Sensory neuropeptides induce histamine release from bronchoalveolar lavage cells in both nonasthmatic coughers and cough variant asthmatics. Clin Exp Allergy 2000;30:225-232.

7 Birring SS, Parker D, Brightling CE, Bradding P, Wardlaw AJ, Pavord ID: Induced sputum inflammatory mediator concentrations in chronic cough. Am J Respir Crit Care Med 2004;169:15-19.

$>8$ Fish JE, Jameson LS, Albright A, Norman PS: Modulation of the bronchomotor effects of chemical mediators by prostaglandin F2 alpha in asthmatic subjects. Am Rev Respir Dis 1984;130:571-574.

9 Kharitonov SA, Sapienza MA, Barnes PJ, Chung KF: Prostaglandins E2 and F2alpha reduce exhaled nitric oxide in normal and asthmatic subjects irrespective of airway caliber changes. Am J Respir Crit Care Med 1998;158:1374-1378.

-10 Choudry NB, Fuller RW, Pride NB: Sensitivity of the human cough reflex: effect of inflammatory mediators prostaglandin E2, bradykinin, and histamine. Am Rev Respir Dis 1989;140:137-141.

-11 Ishiura Y, Fujimura M, Yamamori C, Nobata K, Myou S, Kurashima K, Takegoshi T: Thromboxane antagonism and cough in chronic bronchitis. Ann Med 2003;35:135139.

12 Parsons WG 3rd, Roberts LJ 2nd: Transformation of prostaglandin D2 to isomeric prostaglandin F2 compounds by human eosinophils. A potential mast cell-eosinophil interaction. J Immunol 1988;141:2413-2419.

$\checkmark 13$ Hwang SW, Cho H, Kwak J, Lee SY, Kang CJ, Jung J, Cho S, Min KH, Suh YG, Kim D, Oh $\mathrm{U}$ : Direct activation of capsaicin receptors by products of lipoxygenases: endogenous capsaicin-like substances. Proc Natl Acad Sci USA 2000;97:6155-6160.
14 Takemura M, Quarcoo D, Niimi A, Dinh QT, Geppetti P, Fischer A, Chung KF, Groneberg DA: Is TRPV1 a useful target in respiratory diseases? Pulm Pharmacol Ther 2008;21: 833-839.

15 Nathan RA, Bernstein JA, Bielory L, Bonuccelli CM, Calhoun WJ, Galant SP, Hanby LA, Kemp JP, Kylstra JW, Nayak AS, O'Connor JP, Schwartz HJ, Southern DL, Spector SL, Williams PV: Zafirlukast improves asthma symptoms and quality of life in patients with moderate reversible airflow obstruction. J Allergy Clin Immunol 1998; 102:935-942.

16 Montuschi P, Mondino C, Koch P, Ciabattoni G, Barnes PJ, Baviera G: Effects of montelukast treatment and withdrawal on fractional exhaled nitric oxide and lung function in children with asthma. Chest 2007;132: 1876-1881.

17 Biernacki WA, Kharitonov SA, Biernacka HM, Barnes PJ: Effect of montelukast on exhaled leukotrienes and quality of life in asthmatic patients. Chest 2005;128:1958-1963.

18 Dicpinigaitis PV, Dobkin JB, Reichel J: Antitussive effect of the leukotriene receptor antagonist zafirlukast in subjects with coughvariant asthma. J Asthma 2002;39:291-297.

19 Spector SL, Tan RA: Effectiveness of montelukast in the treatment of cough variant asthma. Ann Allergy Asthma Immunol 2004;93:232-236

20 Kita T, Fujimura M, Ogawa H, Nakatsumi Y, Nomura S, Ishiura Y, Myou S, Nakano S: Antitussive effects of the leukotriene receptor antagonist montelukast in patients with cough variant asthma and atopic cough. Allergol Int 2010;59:185-192.

21 Kohno S, Ishida T, Uchida Y, Kishimoto H, Sasaki H, Shioya T, Tokuyama K, Niimi A, Nishi K, Fujimura M, Matsuse H, Suzaki H The Japanese Respiratory Society guidelines for management of cough. Respirology 2006; 11(suppl 4):S135-S186.

22 Goldman MD: Clinical application of forced oscillation. Pulm Pharmacol Ther 2001;14: 341-350.

23 Morice AH, Fontana GA, Belvisi MG, Birring SS, Chung KF, Dicpinigaitis PV, Kastelik JA, McGarvey LP, Smith JA, Tatar M, Widdicombe J; European Respiratory Society (ERS): ERS guidelines on the assessment of cough. Eur Respir J 2007;29:1256-1276.

24 Takemura M, Niimi A, Minakuchi M, Matsumoto $\mathrm{H}$, Ueda $\mathrm{T}$, Chin $\mathrm{K}$, Mishima $\mathrm{M}$ : Bronchial dilatation in asthma: relation to clinical and sputum indices. Chest 2004;125: 1352-1358.

25 Jinnai M, Niimi A, Ueda T, Matsuoka H, Takemura M, Yamaguchi M, Otsuka K, Oguma T, Takeda T, Ito I, Matsumoto $\mathrm{H}$, Mishima $\mathrm{M}$ : Induced sputum concentrations of mucin in patients with asthma and chronic cough. Chest 2010;137:1122-1129.
26 Spanevello A, Vignola AM, Bonanno A, Confalonieri M, Crimi E, Brusasco V: Effect of methacholine challenge on cellular composition of sputum induction. Thorax 1999; 54:37-39.

27 Yamaguchi M, Niimi A, Ueda T, Takemura M, Matsuoka H, Jinnai M, Otsuka K, Oguma $\mathrm{T}$, Takeda T, Ito I, Matsumoto $\mathrm{H}$, Hirai T, Chin K, Mishima M: Effect of inhaled corticosteroids on small airways in asthma: investigation using impulse oscillometry. Pulm Pharmacol Ther 2009;22:326-332.

28 Takeda T, Oga T, Niimi A, Matsumoto H, Ito I, Yamaguchi M, Matsuoka H, Jinnai M, Otsuka K, Oguma T, Nakaji H, Chin K, Mishima M: Relationship between small airway function and health status, dyspnea and disease control in asthma. Respiration 2010;80: 120-126.

29 Matsumoto H, Niimi A, Jinnai M, Nakaji H, Takeda T, Oguma T, Otsuka K, Inoue H, Yamaguchi M, Matsuoka H, Ito I, Hirai T, Chin K, Mishima M: Association of alveolar nitric oxide levels with pulmonary function and its reversibility in stable asthma. Respiration 2011;81:311-317.

30 Oostveen E, MacLeod D, Lorino H, Farre R, Hantos Z, Desager K, Marchal F: The forced oscillation technique in clinical practice: methodology, recommendations and future developments. Eur Respir J 2003;22:10261041.

31 Marotta A, Klinnert MD, Price MR, Larsen GL, Liu AH: Impulse oscillometry provides an effective measure of lung dysfunction in 4-year-old children at risk for persistent asthma. J Allergy Clin Immunol 2003;112: 317-322.

32 Miller MR, Crapo R, Hankinson J, Brusasco V, Burgos F, Casaburi R, Coates A, Enright P, van der Grinten CP, Gustafsson P, Jensen R, Johnson DC, MacIntyre N, McKay R, Navajas D, Pedersen OF, Pellegrino R, Viegi G, Wanger J: General considerations for lung function testing. Eur Respir J 2005;26:153161.

-33 Niimi A, Matsumoto H, Ueda T, Takemura M, Suzuki K, Tanaka E, Chin K, Mishima M, Amitani R: Impaired cough reflex in patients with recurrent pneumonia. Thorax 2003;58: 152-153.

34 Takishima T, Hida W, Sasaki H, Suzuki S, Sasaki T: Direct-writing recorder of the dose-response curves of the airway to methacholine. Chest 1981;80:600-606

35 Niimi A, Matsumoto H, Takemura M, Ueda T, Chin K, Mishima M: Relationship of airway wall thickness to airway sensitivity and airway reactivity in asthma. Am J Respir Crit Care Med 2003;168:983-988. 
-36 Kraft M, Cairns CB, Ellison MC, Pak J, Irvin C, Wenzel S: Improvements in distal lung function correlate with asthma symptoms after treatment with oral montelukast. Chest 2006;130:1726-1732.

-37 Kawai S, Baba K, Matsubara A, Shiono H, Okada T, Yamaguchi E: The efficacy of montelukast and airway mast cell profiles in patients with cough variant asthma. J Asthma 2008;45:243-250.

-38 Chaudhuri R, McMahon AD, Thomson LJ, MacLeod KJ, McSharry CP, Livingston E, McKay A, Thomson NC: Effect of inhaled corticosteroids on symptom severity and sputum mediator levels in chronic persistent cough. J Allergy Clin Immunol 2004;113: 1063-1070.

>39 Jatakanon A, Lalloo UG, Lim S, Chung KF, Barnes PJ: Increased neutrophils and cytokines, TNF-alpha and IL-8, in induced sputum of non-asthmatic patients with chronic dry cough. Thorax 1999;54:234-237.

40 Groneberg DA, Niimi A, Dinh QT, Cosio B, Hew M, Fischer A, Chung KF: Increased expression of transient receptor potential vanilloid-1 in airway nerves of chronic cough. Am J Respir Crit Care Med 2004;170: 1276-1280.

-41 Montuschi P, Mondino C, Koch P, Barnes PJ, Ciabattoni G: Effects of a leukotriene receptor antagonist on exhaled leukotriene E4 and prostanoids in children with asthma. J Allergy Clin Immunol 2006;118:347-353.

-42 Austen KF, Maekawa A, Kanaoka Y, Boyce JA: The leukotriene E4 puzzle: finding the missing pieces and revealing the pathobiologic implications. J Allergy Clin Immunol 2009;124:406-414, quiz 415-416.

43 Brightling CE, Ward R, Woltmann G, Bradding P, Sheller JR, Dworski R, Pavord ID: Induced sputum inflammatory mediator concentrations in eosinophilic bronchitis and asthma. Am J Respir Crit Care Med 2000; 162:878-882.

44 Pang L, Pitt A, Petkova D, Knox AJ: The COX-1/COX-2 balance in asthma. Clin Exp Allergy 1998;28:1050-1058.
45 Fujimura M, Hara J, Myou S: Change in bronchial responsiveness and cough reflex sensitivity in patients with cough variant asthma: effect of inhaled corticosteroids. Cough 2005; $1: 5$

46 Lee SY, Kim MK, Shin C, Shim JJ, Kim HK, Kang KH, Yoo SH, In KH: Substance P-immunoreactive nerves in endobronchial biopsies in cough-variant asthma and classic asthma. Respiration 2003;70:49-53.

47 Otsuka K, Niimi A, Matsumoto H, Ito I, Yamaguchi M, Matsuoka H, Jinnai M, Oguma T, Takeda T, Nakaji H, Chin K, Sasaki K, Aoyama N, Mishima M: Plasma substance P levels in patients with persistent cough. Respiration 2011;82:431-438.

48 McAlexander MA, Myers AC, Undem BJ: Inhibition of 5-lipoxygenase diminishes neurally evoked tachykinergic contraction of guinea pig isolated airway. J Pharmacol Exp Ther 1998;285:602-607.

$\checkmark 49$ Lai YL, Lee SP: Mediators in hyperpnea-induced bronchoconstriction of guinea pigs. Naunyn Schmiedebergs Arch Pharmacol 1999;360:597-602.

50 Dicpinigaitis PV, Dobkin JB: Effect of zafirlukast on cough reflex sensitivity in asthmatics. J Asthma 1999;36:265-270

51 Tantisira KG, Drazen JM: Genetics and pharmacogenetics of the leukotriene pathway. J Allergy Clin Immunol 2009;124:422427.

52 Lazarus SC, Chinchilli VM, Rollings NJ, Boushey HA, Cherniack R, Craig TJ, Deykin A, DiMango E, Fish JE, Ford JG, Israel E, Kiley J, Kraft M, Lemanske RF Jr, Leone FT, Martin RJ, Pesola GR, Peters SP, Sorkness CA, Szefler SJ, Wechsler ME, Fahy JV: Smoking affects response to inhaled corticosteroids or leukotriene receptor antagonists in asthma. Am J Respir Crit Care Med 2007; 175:783-790.

53 Korenblat PE, Kemp JP, Scherger JE, Minkwitz MC, Mezzanotte W: Effect of age on response to zafirlukast in patients with asthma in the Accolate Clinical Experience and Pharmacoepidemiology Trial (ACCEPT). Ann Allergy Asthma Immunol 2000;84:217225.
-54 Tsai JJ, Chan SC, Ho CK, Su YC, Feng TC: Efficacy of zafirlukast in the treatment of patients with bronchial asthma. J Microbiol Immunol Infect 2001;34:63-70.

55 Creticos P, Knobil K, Edwards LD, Rickard KA, Dorinsky P: Loss of response to treatment with leukotriene receptor antagonists but not inhaled corticosteroids in patients over 50 years of age. Ann Allergy Asthma Immunol 2002;88:401-409.

56 Brightling CE, Monterio W, Green RH, Parker D, Morgan MD, Wardlaw AJ, Pavord $\mathrm{D}$ : Induced sputum and other outcome measures in chronic obstructive pulmonary disease: safety and repeatability. Respir Med 2001;95:999-1002.

57 Birring SS, Prudon B, Carr AJ, Singh SJ, Morgan MD, Pavord ID: Development of a symptom specific health status measure for patients with chronic cough: Leicester Cough Questionnaire (LCQ). Thorax 2003;58:339343.

58 Morice AH, McGarvey L, Pavord I; British Thoracic Society Cough Guideline Group: Recommendations for the management of cough in adults. Thorax 2006;61(suppl 1):i1i24.

59 Niimi A, Matsumoto H, Minakuchi M, Kitaichi M, Amitani R: Airway remodelling in cough-variant asthma. Lancet 2000;356: 564-565.

60 Matsumoto H, Niimi A, Takemura M, Ueda T, Tabuena R, Yamaguchi M, Matsuoka H, Hirai T, Muro S, Ito Y, Mio T, Chin K, Nishiyama $\mathrm{H}$, Mishima M: Prognosis of cough variant asthma: a retrospective analysis. J Asthma 2006;43:131-135.

-61 Takemura M, Niimi A, Matsumoto H, Ueda T, Yamaguchi M, Matsuoka $H$, Jinnai $M$, Chin K, Mishima M: Atopic features of cough variant asthma and classic asthma with wheezing. Clin Exp Allergy 2007;37: 1833-1839. 